\title{
Auction Of Execution Confiscated And National Confiscated
}

\author{
Cucuk Hariyadi ${ }^{1}$, Timbul Mangaratua Simbolon ${ }^{2}$ and Gunarto ${ }^{3}$
}

Abstract. The applicants auction sellers often in practice face prosecution or a lawsuit from a third party that the goods to be auctioned are their own and not the property of those who had been cut with a criminal offense, as it sometimes is the case / light after the auction conducted and considered have been completed. In addition to the auction buyer after he mastered the goods purchased from the auction process also sometimes face prosecution or a lawsuit from a third party that the goods he bought from the auction is actually owned by third parties. The purpose of this study is to analyze the legal protection given to the rightful owner of the auction the buyer of goods or execution of plunder and spoils the country carried out by KPKNL Yogyakarta. This type of research is empirical. Source data using primary and secondary data. The data were analyzed descriptively qualitative. The results showed that the form of legal protection to each of the parties related to the auction execution of plunder and booty state 1) Acting as seller / applicant auction execution is the police or the prosecutor.; 2) To the owner of the goods / owner beginning of good will get legal protection to prevent the auction execution if the auction is not conducted through the path objections / rebuttals, however, if the auction had been implemented, the original owner can file a lawsuit with the District Court, if based on the decisions of the Court the country was the original owner declared right then he can ask them to buyers KPKNL that the goods be returned; 3 ) To the auction buyers who have a good-faith execution of legal protection in the form of refund of the purchase that have been paid without any deduction. but if the auction had been implemented, the original owner can file a lawsuit with the District Court, if based on the District Court declared the original owner right then he can ask to the buyer that the goods be returned KPKNL.

Keywords: Legal Protection; The Auction Execution; KPKNL Yogyakarta.

\section{Introduction}

Auction as an alternative way of sale of goods has long known. But commonly understood meaning is still ambiguous. Often confused with the auction of goods / services in the framework of the implementation of Revenue and Expenditure Budget. Auction bidding is often known by auction on this chartering Nomor.16 stipulated in Presidential Decree 1994 on the Implementation of the State Budget. In this regard, the buyer (government) to deal with sellers who offer goods / services. ${ }^{4}$ Execution or enforcement of the award is the action taken by force against the losing party in a case. In terms of jurisdiction, then the execution according to civil law are running the verdict which has been binding. Implementation can be done by force with the help of the state, if the defendant (the loser) are not satisfied the judgment

1 Student of Master Program (S2) of Notaries Faculty of Law Universitas Islam Sultan Agung email chri4cucuk@gmail.com

2 Students of Master of Law, Faculty of Law, Universitas Islam Sultan Agung email mangarasimbolon777@gmail.com

3 Professor of Faculty of Law UNISSULA Semarang

${ }^{4}$ Sutarjo 1995 Pelelangan dalam Rangka Eksekusi oleh Pengadilan Negeri dan PUPN serta Aspek-aspek Hukum yang Timbul dalam Praktek PUPN Medan p. 22. 
voluntarily, then the way the enforcement (execution) provided for in Article 195 or Article 206 HIR Rbg and later chapters. ${ }^{5}$

At the auction execution of loot and plunder countries acting as the applicant auction / auction seller is the Prosecutor or the Police or Civil Servant Investigators who handled the case, while acting as the buyer is the general public who are interested to participate in the auction knows through the announcements delivered by officials of the Auction. The applicants auction / auction sellers often in practice face prosecution or a lawsuit from a third party that the goods to be auctioned are their own and not the property of those who had been cut with a criminal offense, as it sometimes is the case / light after the auction conducted and considered have been completed.

\section{Research Methods}

This research approach is empirical jurisdiction. Through a juridical approach, this research is conducted by:

"Yuridical research conducted an inventory, describe, interpret and systematize and evaluate the positive law in the whole society activities are directed to efforts to find a settlement jurisdiction over legal issues in society". ${ }^{6}$

To support the juridical data, researchers conducted a study in the field to obtain empirical data. Furthermore, the research method used in this study is a qualitative method. This study is the guest speaker

- Head of the State Property Office and Auction (KPKNL) Yogyakarta

- Officials auction on KPKNL Yogyakarta

\section{Result And Discussion}

\subsection{Implementation of Execution Auction Confiscated Country By KPKNL Yogyakarta}

Article 1 states that the Auction Rules, sales in public is the implementation of the sale of goods in public with ever increasing price quote and or bidding down and down. Participants / auction enthusiasts are people who are interested in participating in the auction or sales execution and be given the opportunity to people who follow the auction to bid and if the price proposed deals can be approved. According to this provision, the sale in public without the presence of officials Auction is not justified unless the public sale held in front of the auctioneer.

Conditions of the auction rules set out in the Decree of the Minister of Finance 337 / KMK.01 / 2000 as amended by the Decree of the Minister of Finance Nomor.40 / PMK.07 / 2006 on Implementation Guidelines for Auction in Article 1 through Article 19. As for the execution of the auction under Article 20 to Article 24.

Article 1 paragraph 4 of Regulation of the Minister of Finance of the Republic of Indonesia Number 40 / PMK.07 / 2006 on Implementation Guidelines specify that the auction execution Auction is an auction to execute decision / determination of a court or other documents, in accordance with the legislation in force equivalent that, in order to assist law enforcement. Included in the definition of the execution auction is Auction

\footnotetext{
${ }^{5}$ M. Yahya Harahap 1988 Ruang Lingkup Permasalahan Eksekusi Bidang Perdata PT. Gramedia Pustaka Utama Jakarta p. 5.

${ }^{6}$ Irianto Sulistyowati dan Shidarta 2011 Metode Penelitian Hukum Konstelasi dan Refleksi Yayasan Pustaka Obor Indonesia Jakarta p. 139.
} 
Confiscated Execution according to Article 45 of the Code of Criminal Procedure and Auction Execution Confiscated Goods.

Article 2 of Regulation of the Minister of Finance of the Republic of Indonesia Number 40 / PMK.07 / 2006 determines that any of the auction should be done by or before the official auction unless otherwise stipulated by legislation. As is the Official Auction is the person specifically authorized by the Minister of Finance to implement the sale of goods by auction.

Auction execution must be made treatise auction because the auction treatise is authentic evidence of the sale of goods, the formal requirements that must be met to draw up the minutes of the auction, which had no form of its own. ${ }^{7}$ Thus, if an auction occurs before the execution without any interpreter / auction officials, then this must be reported to the prosecutor, and the prosecutor will prosecute offenders before the criminal courts, and criminal judge will impose criminal sanctions. If the criminal sanctions such as fines are not paid, then the criminal sanctions such as fines will be replaced with imprisonment. If the breach was a legal person, the criminal prosecution and sanctions are imposed on board members who reside in Indonesia. If the board does not exist, then sentenced are those who represent the legal entity. ${ }^{8}$

The money from the auction is deposited in the State Bank on behalf of the applicant's auction with the provisions for the proceeds of the auction of confiscated goods deposited in the State Bank on behalf of authorized investigators as evidence in legal proceedings and if the case is already has permanent legal force, the defendant was found guilty, the proceeds of the auction of confiscated goods as evidence no later than 7 (seven) days remitted to the State Treasury by the public prosecutor in question as executor, or submitted by the public prosecutor to the accused if found not guilty. However, if money auction results on the confiscated goods that have been deposited in the Bank of the Government, it turns out the investigation process can not be continued due to the suspect could not be found, then no later than 1 (one) week after it is issued / published Warrant Termination of Investigation (SP3) by Investigator concerned, the proceeds of the auction of confiscated goods deposited by the investigators in question to the State Treasury. As for the money deposit / deposit booty directly deposited to the State Treasury by KPKNL as revenue attorney. Evidence care / deposit money from the auction of confiscated goods issued by the Bank of the Government, be a substitute for evidence of cases in the prosecution / trial.

If the accused were acquitted or freed from all lawsuits, even though the decision does not have binding legal force, but the verdict on the evidence of the proceeds of the auction immediately handed over to the accused after the trial is completed (Article 192 paragraph 2 Criminal Code), or if no verdict on the evidence such as, but the decision has permanent legal force, money auction results submitted by the Prosecutor as excecutor to the defendant and if the defendant was sentenced removal and the decision has permanent legal force, money deposited by the Attorney auction proceeds to the State Treasury as executor.

\subsection{Legal Protection Against Own Goods and Execution Auction Buyers Goods Confiscated and State Performed by KPKNL}

${ }^{7}$ Rochmat Soemitro 1987 Peraturan dan Instruksi Lelang PT. Eresco Bandung

p. 114.

${ }^{8}$ Ibid. p. 116. 
Based on the interview with Mr. Priyono N., SE., As Head Section of Documentation and Potential Auction Yogyakarta KPKNL obtained information that in the implementation of the execution of the foreclosure auction and swag state to related parties are given legal protection in accordance with the provisions of the legislation applicable. Granting legal protection to related parties is given by KPKNL if all the requirements in the organization of the auction execution at the request of the seller (the police or Prosecutor) has fulfilled all so the auction execution can be carried out.

According to the provisions of Article 18 and Article 19 of the Regulation of the Minister of Finance Nomor.40 / PMK.07 / 2006 on Implementation Guidelines Auction is determined that the sale by auction shall be preceded by the announcement of an auction conducted by the seller. In principle, the announcement is carried out through a daily newspaper published in the place the items to be auctioned are located. Under these provisions meant in order that those who objected to the plan of the auction may submit an objection to KPKNL to convey the reasons for the objection and from the evidence required.

According to Mr. Priyono N., SE., Obtained information that the original owner of the goods to be auctioned may file a lawsuit to the District Court on the validity of property rights that have been auctioned and if it is found by the District Court decided that the goods were auctioned belonged of the plaintiff (the original owner), the auction buyer is obliged to return the goods. And the good will auction buyer also still get the protection of their rights, namely the purchase money be returned to the buyer without any deductions,

Based on the results of research on legal protection for the parties related to the auction execution of plunder and loot the country, then the legal protection that can be given is:

- Auction Seller / Applicant Auction Execution

Acting as a seller of the auction / auction execution applicant is the Police and the Prosecutor pursuant to the Code of Criminal Procedure. Under these conditions, protection of the law to the police or the Prosecutor based on the provisions of the Code of Criminal Procedure.

- Owner Goods / Own Beginning

To the owner of the goods / owner beginning of good will get legal protection to prevent the auction execution if the auction has not been implemented and if the auction had been implemented, the original owner can file a lawsuit to District Court. When he won it by court decision original owner can later ask them to buyers KPKNL that the goods are returned.

- Buyer Auction Execution

Execution auction to buyers who have a good faith legal protection in the form of refund of the purchase that have been paid in the absence of any piece (back intact).

\section{Closing}

\subsection{Conclusion}

Based on research by the author in Yogyakarta in the auction KPKNL the impression that the execution of the auction execution as if it is identical to the execution or the sale of goods at bargain prices, the sale of secondhand goods and so on. Yet the impression is not correct because there are many different types of items are auctioned, both new stuff and used goods, chattels and immovable goods, even goods 
production, commodity (fuel) as well as goods ex-imported at this time has been auctioned execution through KPKNL Yogyakarta.

In principle, the parties related to the auction execution of plunder and loot the country by KPKNL Yogyakarta given legal protection in accordance with the laws applicable. The form of legal protection to each of the parties related to the auction execution of plunder and loot the state is as follows:

- Seller / Applicant Auction Execution. Acting as seller / applicant auction execution is the police or the prosecutor. For the legal protection granted under the provisions of the Code of Criminal Procedure. Indeed, no one can guarantee that if it turns out later emerged the true owner of the goods to be auctioned, but at least if the procedure Criminal Procedure Code and the terms of the auction have been met by the applicant auction without any exception and is strictly enforced and executed properly, the risk of that will arise in the future can be minimized.

- Owner Goods / Own Beginning. To the owner of the goods / owner beginning of good will get legal protection to prevent the auction execution if the auction is not conducted through the path objections / rebuttals, however, if the auction had been implemented, the original owner can file a lawsuit with the District Court, if based on the decision of the District Court the original owner declared right then he can ask them to buyers KPKNL that the goods are returned. Here is a function to assist technically KPKNL refunds from the state treasury as a whole to be handed to the winning bidder at once attractive goods that have been bought to be returned to the original owner.

- Buyer Auction Execution. Execution auction to buyers who have a good faith legal protection in the form of refund of the purchase that have been paid in the absence of any piece (intact). To remember that we must not say which one is entitled to, because both the initial owner and later owned by the winner of the auction they are equally entitled to the goods object of the auction.

\subsection{Suggestion}

- In order to provide legal certainty and legal protection to the parties related to the auction execution of plunder and loot the country should be the government together with the House of Representatives (DPR) will soon make the Law on changes in the applicable regulations for the implementation of auctions integrated and codified and enforceable standard for all types of auctions, because the auction rules are now in effect long enough, but the dynamics of the auction is closely linked to the business world are increasingly sped far ahead to follow the dynamics of the age.

- To the owner of the goods / original owner who has a good faith should be given the protection of the right to goods that have already auctioned without having to wait for the court decision, even though we know that this country based on law. KPKNL and the Attorney / Police could be given greater access so that they are willing to do a search and investigation on the origin of goods to be auctioned in detail.

\section{References}

[1] Bungin Burhan 2001 Metodologi Penelitian Kualitatif PT Raja Grafindo Persada Jakarta. 
[2] Irianto Sulistyowati dan Shidarta 2011 Metode Penelitian Hukum Konstelasi dan Refleksi Yayasan Pustaka Obor Indonesia Jakarta.

[3] Lexy. J Moleong 2007 Metodologi Penelitian Kualitatif Remaja Rosda Karya Bandung.

[4] M. Yahya Harahap 1988 Ruang Lingkup Permasalahan Eksekusi Bidang Perdata PT. Gramedia Jakarta.

[5] Phillipus M. Hadjon 1987 Perlindungan Hukum Bagi Rakyat Sebuah Studi Tentang Prinsip-Prinsipnya Penanganannya oleh Pengadilan dalam Lingkungan Peradilan Umum dan Pembentukan Peradilan Administrasi Negara Bina Ilmu Surabaya.

[6] Suharsimi Arikunto 2006 Metode Penelitian: Prosedur Penelitian Suatu Pendekatan Praktik Rineka Cipta Jakarta.

[7] Yos Johan Utama 1995 Upaya Perlindungan Hukum Bagi Masyarakat yang Dilakukan oleh Peradilan Tata Usaha Negara Bahan Diskusi untuk Forum Diskusi Fakultas Hukum Universitas Diponegoro Semarang.

[8] Rochmat Soemitro 2009 Peraturan dan Instruksi Lelang Edisi Kedua PT. Eresco Bandung.

[9] Purnama T. Sianturi 2008 Perlindungan Hukum terhadap Pembeli Barang Jaminan Tidak Bergerak Melalui Lelang CV. Mandar Maju Bandung.

[10] Sari Pratama Putriningsih R. Benny Riyanto Marjo 2016 Prosedur Penjualan Lelang atas Aset Kendaraan Milik Universitas Diponegoro Diponegoro Law Journal Volume 5 Nomor 3 Tahun 2016 diakses melalui https://ejournal3.undip.ac.id/index.php/dlr/article/viewFile/.../11737

[11] Decree of the Head of State Receivables and Auction Affairs Nomor.42 / PN / 2000 on Technical Guidelines for Auction

[12] Minister of Finance Decree No. 40 / PMK.07 / 2006 on Implementation Guidelines for Auction

[13] Regulation of the Minister of Finance No. 158 / PMK.06 / 2013 on change Financial Ministry Regulation No. 174 / PMK.06 / 2010 About Officer Class I Auction

[14] Finance Minister Regulation No. 03 / PMK.06 / 2011 on the Management of State Property Originating from Goods Confiscated by the State and Gratification Goods 